\title{
FACTORS INFLUENCING POSITIVE CUSTOMER EXPERIENCES ONLINE
}

\author{
Rasa SMALIUKIENĖ, Dominykas KREGŽDË* \\ Faculty of Business Management, Vilnius Gediminas Technical University, \\ Saulètekio al. 11, 10221, Vilnius, Lithuania \\ *E-mail dominykas.kregzde@stud.vgtu.lt
}

\begin{abstract}
The main purpose of this article is to identify factors and measure their influence on creation of positive customer experiences online. Methods that are used in this article are literature analysis for factor identification and Analytic Hierarchy Process, Kendall coefficient of expert competence and TOPSIS method to assess the influence that identified factors have on creation of positive customer experience online. For the conducted research, two groups of respondents were used. One group consisted of experts from fields related to the topic of this article and another was a group of target audience who responded to given questions. Research revealed how each factor influences creation of positive customer experiences online. In addition to this, companies from a similar business field were ranked using TOPSIS method based on how each factor affects each company.
\end{abstract}

Keywords: online environment, positive customer experience, factors, influence, design, online shopping.

\section{Introduction}

Businesses have to operate in a very tight competitive environment. It is becoming harder to stand out from rival companies and attract new customers because the business environment is changing fast, companies are improving, new marketing techniques are being invented and each day there are new businesses that offer new products or services to the market. These changes are happening so fast that, if organizations do not react, their image and survival will be in danger (Arsezen-Otamis \& Babacan, 2017). As products and services are being created each day, often copying each other, it is becoming difficult to stand out from the competition. It has never been easier for a customer to find a substitute product based on his or her needs and wants (Arens \& Hamilton, 2016). Companies are putting more pressure into maintaining a strong brand image in its customers' eyes and investing more resources into business processes that help in attracting new clients and staying relevant in the market (Kramoliš \& Kopečková, 2013). More and more emphasis is being put towards standing out in the online market. One of the best ways to maintain a strong brand image and attract new customers is the use of social media. It has helped many brands be visible to the public and create a channel through which customers can access a brand and see what it stands for (Gavurova et al., 2018). However, as the technology that we use today reached new heights, customers began demanding a higher level of quality in their online experiences (McLean \& Wilson, 2016). That is why different methods of creating positive customer experiences online are analysed and explained in this paper.

Research problem is which factors influence the creation of positive customer experiences online and how it could be assessed. In addition to this, the research object covers the influence of factors when creating positive customer experiences online while the research aim is to identify what factors and how to assess their influence on the creation of positive customer experiences online.

Research objectives:

1. To analyze scientific literature regarding the creation of positive customer experiences online.

2. Evaluate the influence of factors on the creation of positive customer experiences online based on the conducted empirical research.

Literature analysis together with empirical data analysis such as Kendall coefficient of expert competence, AHP and TOPSIS are used as research methods in order to analyze the topic of this paper. 


\section{Understanding factors of positive customer experience online}

For a business it is important to position itself in the online environment as best as it can so that customers can be attracted by offered products or services. The abundance of online channels through which a customer can interact with a business has put more pressure on company's activities (Cambra-Fierro et al., 2019).

Attracting customer's attention has never been more difficult. The abundance of products in a market has made it easier for a customer to switch from one product to another (Petit et al. 2019). In order to attract customer's attention towards a product or a service that a businesses is offering, visual aid is required (Pandey \& Chawla, 2018). As Martin, Mortimer, and Andrews (2015) stated in their research, visually appealing stimuli not only attracts customer's attention but it plays a huge role whether a product or a service will be sold or not. Having a presence on social media channels might still not be enough to persuade a customer to trust a brand and make a purchase. Brands, like never before, have to find new ways to position themselves online accordingly to what the customer is expecting (Lamont, 2014). Thus, many users have started seeking for a more interactive experience online. More importantly, it is the influence of digital channels over shopping decisions of customers that make companies remember that in order to gain more market share, digitalization of a company's activities is imminent (Tom et al., 2017).

For many businesses and brands, it is important to showcase its products online on a correct platform that would help the production stand out. Pinterest and Instagram have become such platforms where clients can comment on their favorite items and brands can see which products are trending and creating a buzz (Liyakasa, n.d.). As more and more businesses are relocating to online environments, more products and services are being offered and sold through online/digital channels (Stavljanin \& Pantovic, 2017).

In addition, the growing influence of internet in customers' everyday lives, it has become important for a client to feel safe while scrolling and making purchases online (Akhter, 2014). With many online transactions being completed everyday, it has become a key factor for a business to maintain its' clients' privacy and create a safe online environment.

\subsection{Social media presence}

One of activities that faced enormous pressure during the last few years of the boom of social media is customer support. Users have grown accustomed to using multiple channels at once in order to receive customer support from a company as fast as possible (Sargent, 2016). But having multiple social media accounts for a business is not enough to please a customer. The presence of a business has to be felt on a platform where it has an account. Customers want to be heard and replied to when they encounter a problem but sometimes company's empathy is nowhere to be found. Companies that have Twitter and Facebook accounts respond to only $60 \%$ of the tweets and $76 \%$ of messages directed towards Twitter's and Facebook's accounts respectively (Klie, 2015). One of the key factors of maintaining a positive customer experience and showing a strong social media presence is time of reaction. When a customer reaches out to a company through social media, $79 \%$ of clients expect to get a response within 15 minutes (Klie, 2015). Customers have become really impatient and wish for a fast responding service (Lamont, 2012; Sargent, 2016)

Moreover, if a company has social media accounts, it is necessary to have proper and concrete information on them which would guide customers properly and provide them with essential information (Lamont, 2014). Usually, the information that a person is looking for about a business is related to the brand itself. It is important to open the brand to a customer and show willingness from the company's side to engage in a dialogue with the user and provide interesting content (Jaska \& Werenowska, 2014). Also, it allows the company to become transparent and show a part of some processes and activities that are happening within a business.

Furthermore, the most successful brands in the world are consistent in what they are showing to its target audience and consistency brings positive attitude from customers. The more people recognize and believe in a brand, the more willing they are to buy (Chao-Sen, 2015). Customers are quick to decide whether to engage into a shopping process with a company or to ignore messages that a business is sending to its customers. In order to be recognized on social media, a business has to be identifiable and deliver a consistent brand message to its clients which would trigger positive emotions and show brand friendliness (Gavurova et al., 2018). Also, according to an empirical analysis conducted by Faqih (2016), it was revealed that females' attention to brand image can be affected by the amount of products, especially clothes, offered for women. The abundance of products to choose from usually allows customers to have greater e-satisfaction without paying attention to certain details such as brand image (Gavurova et al., 2018).

On the other hand, conducting a thorough social media analysis and managing it consistently adds up to additional expenses for a business. Employees have to be delegated to manage the company's social accounts and deal with customer enquiries. According to Lamont (2014), only less than $10 \%$ of companies measured how many resources does it take to manage a company's social media account. If more attention is put on monitoring and handling social media data, it can have major returns and costs saved for a business (Gibbons, 2018; MacDonald, 2012). 


\subsection{Online store design}

If a business wishes to attract more customers with its visual appearance online, it is important to decide what color palettes suit sold products or services the best when displaying them in an online environment (Sunaga et al., 2016). As a study conducted by Gatti, Bordegoni, and Spence (2014) showed, that people tend to be attracted more by lighter colors whether it is the background of an online shop or the product itself. Even more interesting is that if an object is placed in front of a dark background, the color of an object intensifies in the viewers eyes which causes more attraction (Salmela \& Vanni, 2013).

Moreover, business's online environment where all the sold products are shown has to have an attractive layout, design and colors. Customers are very picky and tend to quickly escape an online environment where no positive emotions are caused (Wijaya et al., 2019). According to Castro-Lopez, Vazquez-Casielles, and Puente (2019), the longer a business manages to keep its' customer scrolling through its online store, the more likely the client is to make a purchase. This means that a business not only has to invest in how a product looks in real life but also how it looks on an online sales channel. As one research, conducted by Pandey and Chawla (2018), shows that women are more attracted to a webpage which has pleasant design and high quality photos of products.

On the other hand, sometimes businesses tend to pay too much attention at how their online environment looks and forget a key factor in creating positive customer emotions online - time. As Lamont (2012) stated, "Customers are increasingly impatient with cumbersome purchase processes or unresponsive service". For a business it is important to help customer save as much time as possible while he or she is making a purchase. Which is why a fast response rate on a webpage while clicking various items is as important as the item itself (Micu et al., 2019; Rose et al., 2012). In addition to this, the skill level of online shoppers has been increasing consistently which means that businesses have to keep up with their webpage technology and speed in order to attract a customer (Luo et al., 2012; Nilashi \& Ibrahim, 2012).

Furthermore, as Khan \& Rahman (2016) mentioned in their conducted research, customers are more likely to buy a product when the purchase process is easy to understand and navigate through. When a purchase can be made with only a few clicks of a button, a customer does not have enough time to reevaluate his intention of buying. This sometimes leads to a customer making a purchase while not really needing the bought item/product (Barari et al., 2020). Also, as Tandon, Kiran, and Sah (2016) state, online customers are more likely to make a purchase if they find the overall design and outlook of an online shop appealing.

\subsection{Interactive experience online}

For a business it is essential to decide on a correct target audience since they will be the main buyers of products or services. Many people have different preferences when it comes to shopping online, thus different expectations need to be met. As Hao Suan Samuel, Balaji, and Kok Wei (2015) stated in their research analysis, - "the female customers were found to be influenced by the uniqueness, social interaction, assortment, and browsing aspects of shopping experience". Online shoppers crave for experience during their shopping. One research even found that if a female buyer is lacking social and interpersonal interaction during her online shopping experience, then the shopper might stop trusting the online retailer (Hao Suan Samuel et al., 2015; Pandey \& Chawla, 2018). This means that a business has to increase investments into its processes and activities regarding social media in order to make customers happy (MacDonald, 2012).

Moreover, for many years, businesses have been limited in ways how to be interactive with customers through online channels. Main possibilities were stimulating customers through visual and audio technology such as screens and headphones. But the technological landscape has been shifting for a few years where new technologies are constantly being introduced (Stavljanin \& Pantovic, 2017). As a result of that, new technologies to allow users to be more interactive with a brand and its products in an online environment have been created, such as virtual reality, augmented reality and digital taste and smell simulators (Petit et al., 2019). All of these can be used as a way to market a product and give new opportunities to marketers to attract customers (Spapé et al., 2015). In addition to this, those brands or websites that offer its customers interactive experiences, have a better chance of making a sale and creating a positive customer experience (McLean \& Wilson, 2016).

On the other hand, it was thought that services that are being provided through an online environment are inferior to the ones that are provided in real life when a customer is interacting with employees (Goldenberg, 2017). Customers are still seeking reassurance and consultation from the staff since some people believe that a problem can be solved much faster when interacting with a real person instead of a digital customer support agent (Lallemand et al., 2015). Moreover, customers tend to be affected by other customers in a physical environment when making purchase decisions. Emotions are affected the most which then determine whether a purchase will be made or not (McLean \& Wilson, 2016). While there are many instances when the physical surrounding can affect purchase decision positively, sometimes it can have a negative effect, especially when other shoppers are dissatisfied with their experience (Gavurova et al., 2018). 


\subsection{Safe purchase}

According to Martin et al. (2015), online clients are very sensitive regarding e-security and e-privacy. Based on a research conducted by Pandey and Chawla (2018), it was revealed that women tend to have a higher level of distrust while shopping through online retail stores because of an escalated fear of being robbed or personal details being stolen. While women are more likely to press on a colorful banner that suddenly appeared on a screen, they tend to be more cautious about the conditions of a proposed discount (Meyers-Levy \& Loken, 2015). However, this opinion is neglected by Pandey and Chawla (2018) who in their research state that women care less than men regarding privacy policies and other purchase related rules. This means that women are easier to persuade to make a purchase online and as Khan, Rahman, \& Fatma (2016) suggest in their research, women will return for another purchase if they had a pleasant experience and they feel that they can trust the seller.

Furthermore, Pappas et al. (2014) in their conducted research found out that the significance of a relationship between customer satisfaction and trust when making a purchase online does not change even when taking into consideration experience level of a buyer. Which means that if a buyer is more experienced in purchasing products online, it does not increase or decrease his or her satisfaction when buying online products. In addition to this, as Pandey and Chawla (2018) state in their research, more experienced online shoppers tend to skip the information on a webpage which is meant to help navigate the shopping process for a user. This is because that experienced shoppers already know the process and do not need help with it (Rezaei, 2014).

Also, according to a research conducted by Tandon, Kiran, and Sah (2016), people have started to turn more towards online shopping without fearing of being scammed because of a possibility to pay on the spot only when the products are delivered. This allows customers to feel safer about their purchases (Rawat \& Sharma, 2014). Moreover, as Thakur and Srivastava (2015) found out from their conducted research, people are afraid to share any of their personal details, be it email or credit card number, because of spam, unwanted communication with third parties or promotional offerings. This creates an obstacle for businesses because they have to create more simple and trustworthy ways for customers to purchase products or services (Hao Suan Samuel et al., 2015).

\section{Methodology}

The main purpose of this research is to take a more in-depth look at factors that have influence on creating positive customer experiences online. Based on literature analysis, 4 factors were chosen that have an effect on customer experiences:

1. Social media presence;

2. Online store design;

3. Interactive experience online;

4. Safe purchase.

Certain statistical methods are used as tools to determine which factors have the highest importance or, in other words, highest weights and how do they rank in importance. In order to see the true impact that these 4 factors have, first method that is used is Kendall's coefficient of competence. This method is most suitable for measuring the competence of people who are regarded as experts in their fields. For this research, 6 experts were questioned regarding the 4 factors that have an influence on positive customer experience. Based on their answers, Kendall's coefficient of competence method was applied and competence levels for each expert that responded was calculated (Gedvilaitè, 2019).

Firstly, general coefficient of competence for all experts is calculated with the following formula 1.

$$
K_{i}^{0}=\frac{1}{m}, \quad j=1, \ldots, m,
$$

where: $K_{i}^{0}-$ general coefficient of competence; $m$ - number of experts.

Further, a new matrix $x_{j}^{t}$ is created by using formula 2 where each value from initial matrix $x_{i j}$ is multiplied by group estimates of every $j$ factor and by the sum of $j$ factor's values.

$$
x_{j}^{t}=\sum_{i=1}^{m} K_{i}^{t-1} \cdot x_{i j}, \quad j=1, \ldots, n,
$$

where: $x_{j}^{t}$ - values of $x$ matrix's $j$ object; $\sum_{i=1}^{m} K_{i}^{t-1}$ - group estimates of $i$ factor; $x_{i j}$ - initial values of $j$ object's $i$ factor; $j$-factor rank; $n$-number of objects.

Lambda is calculated by summing up all values from the new matrix (see formula 3 ). 


$$
\lambda^{t}=\sum_{j=1}^{n} \sum_{i=1}^{m} x_{j}^{t} \cdot x_{i j}
$$

where: $\lambda^{t}$ - lambda; $\sum_{j=1}^{n} \sum_{i=1}^{m} x_{j}^{t}-$ sum of all $x$ matrix values; $x_{i j}$-initial $i$ factor's $j$ object's value.

For the coefficient of competence of each expert, formula 4 is used where the sum of each expert's values from the new matrix is divided by lambda from previous formula 3.

$$
K_{i}^{t}=\frac{1}{\lambda^{t}} \cdot \sum_{j=1}^{n} x_{j}^{t} \cdot x_{i j}, \quad \sum_{i=1}^{m} K_{i}^{t}=1
$$

where: $K_{i}^{t}-$ competence coefficient of each expert; $\lambda^{t}-$ lambda; $\sum_{j=1}^{n} x_{j}^{t}-\operatorname{sum}$ of $j$ object's values; $\sum_{i=1}^{m} K_{i}^{t}=1-$ sum of all competence coefficients equals $1 ; x_{i j}$ - initial $i$ factor's $j$ object's value.

If the competence coefficients from formula 4 fall into the interval of formula 5 , that means that all experts are competent.

$$
\bar{K}_{i}^{t}-1.96 s \leq K_{i}^{t} \leq \bar{K}_{i}^{t}+1.96 s
$$

where: $\bar{K}_{i}^{t}$ - average expert competence coefficient; $s$-standard deviation; $K_{i}^{t}$ - competence coefficient of each expert.

As a second tool, AHP (Analytic Hierarchy Process) method is used in order to determine the weights or, in other words, importance of each factor in the contrast of other factors (Osmani \& Kochov, 2018). The higher the weight of a factor, the more important it is in relation to other factors. In order to calculate the weights, an expert has to evaluate each factor in relation to another on a scale from 1 to 9 (Wolnowska \& Konicki, 2019). 1 meaning that both factors are identically important and 9 meaning that one factor is very important and the other has basically no importance. Factor which is shown in a row is compared to factor which is shown in a column (Juodagalviené, 2018). If the column factor, or in other words object, value is higher than the row factor value, then the full grade is written in the pairwise comparison matrix. If the row value is higher, then 1 is divided by the given grade. A pairwise comparison matrix can be created as seen in formula 6.

$$
\left[\begin{array}{ccc}
C_{11} & \cdots & C_{1 n} \\
\vdots & \ddots & \vdots \\
C_{n 1} & \cdots & C_{n n}
\end{array}\right]
$$

where: $C_{11}$ - comparison of $1^{\text {st }}$ factor's value with $1^{\text {st }}$ object ; $C_{n 1}$ - comparison of $n$ factor's value with $1^{\text {st }}$ object; $C_{1 n}$ - comparison of $1^{\text {st }}$ factor's value with $n$ object; $C_{n n}$ - comparison of $n$ factor's value with $n$ object.

With formula 7, a normalized pairwise comparison matrix is created. Here, each value of the previously created matrix is divided by the total factor $n$ value (Ng \& Chuah, 2014).

$$
X_{i j}=\frac{C_{i j}}{\sum_{i, j=1}^{n} C_{i j}}=\left[\begin{array}{ccc}
X_{11} & \cdots & X_{1 n} \\
\vdots & \ddots & \vdots \\
X_{n 1} & \cdots & X_{n n}
\end{array}\right],
$$

where: $X_{i j}$ - normalized value of $C_{i j} ; C_{i j}-i$ factor, $j$ value; $\sum_{i, j=1}^{n} C_{i j}-$ sum of $i$ factor's values; $X_{11}-$ normalized $1^{\text {st }}$ factor's $1^{\text {st }}$ value; $X_{n 1}$ - normalized $n$ factor's $1^{\text {st }}$ value; $X_{1 n}$ - normalized $1^{\text {st }}$ factor's $n$ value; $X_{n n}$ - normalized $n$ factor's $n$ value.

Factor weights can be calculated by dividing the sum of each factor's values by the number of factors (see formula 8).

$$
W_{i j}=\frac{\sum_{i=1}^{n} X_{i n}}{n}=\left[\begin{array}{c}
W_{11} \\
\vdots \\
W_{1 n}
\end{array}\right] \text {, }
$$

where: $W_{i j}$ - weight of $i$ factor's $j$ object's value; $\sum_{i=1}^{n} X_{i n}$ - sum of normalized $j$ object's values; $n$ - number of factors; $W_{11}-1^{\text {st }}$ factor weight; $W_{1 n}$ - last factor weight. 
Further, all elements from pairwise comparison matrix are multiplied by the factor weights as seen in formula 9.

$$
C v_{i j}=\left[\begin{array}{ccc}
C_{11} & \cdots & C_{1 n} \\
\vdots & \ddots & \vdots \\
C_{n 1} & \cdots & C_{n n}
\end{array}\right] \times\left[\begin{array}{c}
W_{11} \\
\vdots \\
W_{1 n}
\end{array}\right]=\left[\begin{array}{c}
C v_{11} \\
\vdots \\
C v_{1 n}
\end{array}\right],
$$

where: $C v_{i j}$ - measure of compatibility; $C_{11}$ - comparison of $1^{\text {st }}$ factor's value with $1^{\text {st }}$ object ; $C_{n 1}-$ comparison of $n$ factor's value with $1^{\text {st }}$ object; $C_{1 n}$ - comparison of $1^{\text {st }}$ factor's value with $n$ object; $C_{n n}-$ comparison of $n$ factor's value with $n$ object; $W_{11}-1^{\text {st }}$ factor weight; $W_{1 n}-$ last factor weight; $C v_{11}-1^{\text {st }}$ factor compatibility measure; $C v_{1 n}$ - last factor compatibility measure.

Lambda of each factor is calculated by dividing the the measure of compatibility by factor weight (see formula 10).

$$
\lambda=\frac{C v_{i j}}{W_{i j}},
$$

where: $\lambda$ - lambda; $C v_{i j}$ - measure of compatibility; $W_{i j}$ - weight of $i$ factor's $j$ object's value.

For consistency index calculation formula 11 is used (Osmani \& Kochov, 2018).

$$
C I=\frac{\lambda-n}{n-1},
$$

where: $C I$ - consistency index; $\lambda$ - lambda; $n$ - number of factors.

In order to check if the calculated weights are applicable, compression ratio calculation (see formula 12) is used (Osmani \& Kochov, 2018) Random index value is chosen from Table 1 according to the number of factors that are analyzed.

$$
C R=\frac{C I}{R I}
$$

where: $C R$ - compression ratio; $C I$ - consistency index; $R I$ - random index.

Table 1. Random index (Saaty, 1987)

\begin{tabular}{|c|c|c|c|c|c|c|c|c|c|c|}
\hline$n$ & 1 & 2 & 3 & 4 & 5 & 6 & 7 & 8 & 9 & 10 \\
\hline$R I$ & 0 & 0 & 0.58 & 0.9 & 1.12 & 1.24 & 1.34 & 1.41 & 1.45 & 1.49 \\
\hline
\end{tabular}

AHP method is deemed compatible if the CR value is lower than 0,2 . That means that the calculated weights can be used in further calculations.

After the expert competence coefficients have been determined and factor weights have been calculated, TOPSIS method can be applied which helps in ranking objects according to the weights of factors and according to retrieved answers from respondents (Biswas et al., 2016). This method was chosen because it takes into consideration ideal positive and ideal negative solution which allows to give a more concrete ranking. TOPSIS method can be carried out to rank 4 Lithuanian clothing brand businesses based on the factors that are influencing customer experience online. For this method, a pilot research was carried out creating a survey and asking 20 people to evaluate how each factor is performing for a given business on a scale from 1 to $5-1$ meaning that the factor is poorly applied and 5 meaning good induction of an evaluated factor. For the TOPSIS method, firstly, a matrix with factors and their weights has to be normalized by using formula 13 .

$$
n_{i j}=\frac{x_{i j}}{\sqrt{\sum_{i=1}^{m} x_{i j}^{2}}},
$$

where: $n_{i j}$ - normalized $j$ object's $i$ factor's value; $x_{i j}$ - initial $j$ object's $i$ factor's value; $\sum_{i=1}^{m} x_{i j}^{2}-$ sum of all squared values of $i$ factor.

Further, a weighted matrix is created where each value of a $i$ factor from the normalized matrix is multiplied by the $i$ factor weight (see formula 14). 


$$
v_{i j}=w_{j} n_{i j} \text { for } i=1, \ldots, m ; j=1, \ldots, n,
$$

where: $v_{i j}$-weighted $j$ object's $i$ factor's value; $w_{j}$ - weight of $j$ object $; n_{i j}$ - normalized $j$ object's $i$ factor's value.

Next, ideal positive solutions for each factor are calculated with the help of formula 15 .

$$
V^{+}=\left(v_{1}^{+}, v_{2}^{+}, \ldots, v_{n}^{+}\right)=\left(\left(\max _{i} v_{i j} \mid j \in I\right),\left(\min _{i} v_{i j} \mid j \in J\right)\right),
$$

where: $V^{+}$- ideal positive solution; $I$ - maximazing criteria; $J$ - minimizing criteria; $\underset{i}{\min } v_{i j}-\operatorname{minimum}$ weighted $j$ object's $i$ factor's value; $\max _{i} v_{i j}$ - maximum weighted $j$ object's $i$ factor's value.

Ideal negative solutions are also calculated (see formula 16).

$$
V^{-}=\left(v_{1}^{-}, v_{2}^{-}, \ldots, v_{n}^{-}\right)=\left(\left(\min _{i} v_{i j} \mid j \in I\right),\left(\max _{i} v_{i j} \mid j \in J\right)\right),
$$

where: $V^{-}$- ideal negative solution; $I-$ maximazing criteria; $J$ - minimizing criteria; $\min _{i} v_{i j}-\operatorname{minimum}$ weighted $j$ object's $i$ factor's value; $\max _{i} v_{i j}$ - maximum weighted $j$ object's $i$ factor's value.

After ideal solutions are found by using formulas 15 and 16, distance to ideal solutions need to be calculated with the help of formula 17.

$$
S_{i}^{+}=\sqrt{\sum_{j=1}^{n}\left(v_{i j}-v_{i}^{+}\right)^{2}}, i=1,2, \ldots, m,
$$

where: $S_{i}^{+}-$value of $i$ factor's distance to ideal positive solution; $\sum_{j=1}^{n}\left(v_{i j}-v_{i}^{+}\right)^{2}-\operatorname{sum}$ of all $j$ object's $i$ factor's weighted values substracted by $i$ factor's ideal positive solution.

And distance to ideal solutions are also found with the help of formula 18.

$$
S_{i}^{-}=\sqrt{\sum_{j=1}^{n}\left(v_{i j}-v_{i}^{-}\right)^{2}}, i=1,2, \ldots, m,
$$

where: $S_{i}^{-}-$value of $i$ factor's distance to ideal negative solution; $\sum_{j=1}^{n}\left(v_{i j}-v_{i}^{-}\right)^{2}-$ sum of all $j$ object's $i$ factor's weighted values substracted by $i$ factor's ideal negative solution.

Last step is to calculate relative proximity to the ideal solution (see formula 19).

$$
P_{i}=\frac{S_{i}^{-}}{S_{i}^{-}+S_{i}^{+}}
$$

where: $P_{i}$ - relative proximity to the ideal $i$ factor's solution; $S_{i}^{+}$- value of $i$ factor's distance to ideal positive solution; $S_{i}^{-}$- value of $i$ factor's distance to ideal negative solution.

\section{Research results}

Based on the conducted research analysis, results were obtained. For the research, AHP and Kendall expertise calculation methods were used. In order to begin the research, experts from social media management fields were questioned and according to their answers research was conducted. Firstly, Kendall coefficient of expert competence method was used to determine whether all experts who responded to given questions about factors influencing positive customer experience online are competent and their answers can be trusted. So, during Kendall's method, 6 experts were asked to rank each factor each factor from 1 to $4-1$ meaning that the factor is the most important factor from all 4 , and 4 meaning that the factor has the least importance (see Table 2). 
Table 2. Factor ranking by experts

\begin{tabular}{|c|c|c|c|c|}
\hline Expert & $\begin{array}{c}\text { Safe } \\
\text { purchase }\end{array}$ & $\begin{array}{c}\text { Social media } \\
\text { pressence }\end{array}$ & $\begin{array}{c}\text { Online store } \\
\text { design }\end{array}$ & $\begin{array}{c}\text { Interactive } \\
\text { experience }\end{array}$ \\
\hline 1 & 2 & 1 & 3 & 4 \\
\hline 2 & 1 & 4 & 3 & 2 \\
\hline 3 & 4 & 2 & 1 & 3 \\
\hline 4 & 2 & 3 & 1 & 4 \\
\hline 5 & 3 & 4 & 1 & 4 \\
\hline 6 & 1 & 3 & 2 & \\
\hline
\end{tabular}

Based on the expert answers from Table 2, Kendall coefficient of expert competence calculation method was applied in order to see if all experts are competent. As it can be seen in Table 3, all competence coefficients from questioned experts fall into the competence interval $[0,156 ; 0,177]$. This means that all experts are competent and further research can be carried out with all or either one of the experts.

Table 3. Expert competence coefficients and competence interval

\begin{tabular}{|c|c|}
\hline Competence coefficients of 6 experts & Competence interval \\
\hline 0,162 & \\
\hline 0,162 & \\
\hline 0,164 & \\
\hline 0,174 & \\
\hline 0,166 & \\
\hline 0,172 & \\
\hline
\end{tabular}

After the competence coefficients of all 6 experts revealed that all of them are competent, AHP method could be applied with which factor weights can be determined. For the AHP method, the average evaluation from all experts was taken, meaning that all 6 experts had to evaluate which factor is more superior in relation to another and evaluate the importance from 1 to 9 as seen in Table 4 and an average evaluation was taken. 1 meaning that both factors are equally important while 9 meaning that one factor is widely superior than another.

Table 4. Expert evaluations of factor importance

\begin{tabular}{|l|c|c|l|}
\hline \multicolumn{1}{|c|}{ Safe purchase } & $\mathbf{2}$ & & \multicolumn{1}{c|}{ Social media presence } \\
\hline Safe purchase & & $\mathbf{3}$ & Online store design \\
\hline Safe purchase & $\mathbf{4}$ & & Interactive experience \\
\hline Social media presence & & $\mathbf{3}$ & Online store design \\
\hline Social media presence & $\mathbf{6}$ & & Interactive experience \\
\hline Online store design & $\mathbf{4}$ & & Interactive experience \\
\hline
\end{tabular}

The results from the conducted AHP method revealed that Online store design had the highest weight of 0,477 while Interactive experience had the lowest weight of 0,069 (see Table 5).

Table 5. Factor weights

\begin{tabular}{|l|c|}
\hline \multicolumn{1}{|c|}{ Influencing factor } & Weight \\
\hline Safe purchase & 0,244 \\
\hline Strong social media presence & 0,210 \\
\hline Attractive online store design & 0,477 \\
\hline Interactive experience & 0,069 \\
\hline
\end{tabular}

Compression ratio (CR) was also calculated in order to check if the calculated weights can be used. The value of the calculated compression ratio was 0,127 which is lower than 0,2 and that means that the weights can be used for further calculations. Based on the calculated factor weights, true impact of each factor for each business can be calculated and measured. All factors are in relation to specific companies so respondents had to give their evaluations of factors by looking at a business's online environment, store design and social media accounts. An average answer for every factor and every business was taken (see Table 6). 
Table 6. Evaluations of Lithuanian clothing brands

\begin{tabular}{|l|c|c|c|c|}
\hline \multicolumn{1}{|c|}{ Factor weights } & 0,244 & 0,477 & 0,210 & 0,069 \\
\hline Safe purchase & $\begin{array}{c}\text { Attractive online store } \\
\text { design }\end{array}$ & $\begin{array}{c}\text { Strong social media } \\
\text { presence }\end{array}$ & Interactive experience \\
\hline Confused Mood & 3 & 3 & 3 & 4 \\
\hline Tegul bėga & 3 & 3 & 4 & 4 \\
\hline Labadiena & 5 & 4 & 4 & 3 \\
\hline LeSlap & 5 & 5 & 5 & 3 \\
\hline
\end{tabular}

As the Table 6 shows, each clothing business was given a certain evaluation according to a certain factor. With the help of TOPSIS method, $P i$ value for each business was calculated. $P i$ value shows the relative closeness to the positive ideal solution. The lower the $P i$ value, the lower the rank. As results from Table 7 show, Lithuanian clothing brand LeSlap is ranked $1^{\text {st }}$ which means that this brand has implemented the most important factors determining positive customer experience online correctly.

Table 7. Ranking of Lithuanian clothing brands

\begin{tabular}{|l|c|c|}
\hline \multicolumn{1}{|c|}{ Clothing brand } & $P i$ & Rank \\
\hline Confused Mood & 0,062 & 4 \\
\hline Tegul bejga & 0,165 & 3 \\
\hline Labadiena & 0,569 & 2 \\
\hline LeSlap & 0,938 & 1 \\
\hline
\end{tabular}

While Confused Mood which is ranked $4^{\text {th }}$ had the highest evaluation in Interactive experience which is a high evaluation in comparison with other brands (see Table 7). However Interactive experience factor had the lowest factor weight of 0,069 which means that the business is focusing on the wrong positive customer experience factor online (see Table 5). Businesses, especially Lithuanian clothing brands, need to pay more attention to improving their online store designs since it carries almost a $50 \%$ importance in creating positive customer experiences online which is crucial for a business to succeed in a market.

The research closely resembles each Lithuanian clothing brand and what it tries to achieve with its social media tools and actions. As Labadiena and LeSlap are quite big Lithuanian brands in the clothing industry based on the number of followers and their international recognition, they earned the highest rating from respondents in the Safe purchase factor. This allows to make a conclusion that as a brand is getting more recognizable, the safer people feel when buying from them. This can also be seen from Tegul bèga and Confused Mood that are quite new in the Lithuanian clothing market, thus people do not feel that safe when buying from them which resulted in a rating of only 3 out of 5 in the Safe purchase factor. However, being small and new in a market is not a big drawback. Tegul bèga and Confused Mood received the highest ratings from the 4 brands in this factor mainly because, as some respondents stated, they are more reachable and easier to communicate with.

\section{Conclusions}

1. As the analysis of scientific literature showed, positive customer experience online is influenced by the following factors - online store design, interactive experience, safe purchase and social media presence.

2. Conducted empirical research revealed that of the 4 found factors that have influence on positive customer experience online, online store design has the highest importance on customer satisfaction while interactive experience has the lowest influence on consumer behavior and on business activities.

3. Lithuanian clothing brand LeSlap had the highest rating from all 4 brands because it had the highest ratings in the 3 factors that have the highest importance while Confused Mood had the highest rating in the least important factor which lead to the brand being last.

\section{References}

Akhter, S. H. (2014). Privacy concern and online transactions: The impact of internet self-efficacy and internet involvement. Journal of Consumer Marketing, 31(2), 118-125. https://doi.org/10.1108/JCM-06-2013-0606

Arens, Z. G., \& Hamilton, R. W. (2016). Why focusing on the similarity of substitutes leaves a lot to be desired. Journal of Consumer Research, 43(3), 448-459. https://doi.org/10.1093/jcr/ucw034

Barari, M., Ross, M., \& Surachartkumtonkun, J. (2020). Negative and positive customer shopping experience in an online context. Journal of Retailing and Consumer Services, 53, 101985. https://doi.org/10.1016/j.jretconser.2019.101985

Biswas, P., Pramanik, S., \& Giri, B. C. (2016). TOPSIS method for multi-attribute group decision-making under singlevalued neutrosophic environment. Neural Computing and Applications, 27(3), 727-737.

https://doi.org/10.1007/s00521-015-1891-2 
Cambra-Fierro, J., Xuehui Gao, L., Melero-Polo, I., \& Javier Sese, F. (2019). What drives consumers' active participation in the online channel? Customer equity, experience quality, and relationship proneness. Electronic Commerce Research and Applications, 35, 100855. https://doi.org/10.1016/j.elerap.2019.100855

Castro-Lopez, A., Vazquez-Casielles, R., \& Puente, J. (2019). How to manage the online experience concerning transactional and experimental customers: Case of e-fashion sector. Journal of Business Economics and Management, 20(3), 595617. https://doi.org/10.3846/jbem.2019.9860

Chao-Sen, W. (2015). A study on consumers' attitude towards brand image, athletes' endorsement, and purchase intention. International Journal of Organizational Innovation, 8(2), 233-253.

Faqih, K. M. S. (2016). An empirical analysis of factors predicting the behavioral intention to adopt Internet shopping technology among non-shoppers in a developing country context: Does gender matter? Journal of Retailing and Consumer Services, 30, 140-164. https://doi.org/10.1016/j.jretconser.2016.01.016

Gatti, E., Bordegoni, M., \& Spence, C. (2014). Investigating the influence of colour, weight, and fragrance intensity on the perception of liquid bath soap: An experimental study. Food Quality and Preference, 31(1), 56-64. https://doi.org/10.1016/j.foodqual.2013.08.004

Gavurova, B., Bacik, R., Fedorko, R., \& Nastisin, L. (2018). The customer's brand experience in the light of selected performance indicators in the social media environment. Journal of Competitiveness, 10(2), 72-84. https://doi.org/10.7441/joc.2018.02.05

Gedvilaitè, D. (2019). Šalies regionu darnios plètros vertinimas. Vilniaus Gedimino technikos universitetas. https://doi.org/10.20334/2019-020-M

Gibbons, P. (2018). How do you listen to your customers? You need a listening architecture to get the most from customer insights. CRM Magazine, 22(9), 8. http://search.ebscohost.com/login.aspx?direct=true $\& \mathrm{db}=\mathrm{a} 9 \mathrm{~h} \& \mathrm{AN}=133676801 \&$ site=ehost-live $\&$ scope=site

Goldenberg, B. (2017). CXM: Give your customers the experiences they want. CRM Magazine, 21(April), 6. $\mathrm{http} / / /$ search.ebscohost.com/login.aspx?direct=true \&db=a9h\&AN=122209040\&site=ehost-live\&scope=site

Hao Suan Samuel, L., Balaji, M. S., \& Kok Wei, K. (2015). An investigation of online shopping experience on trust and behavioral intentions. Journal of Internet Commerce, 14(2), 233-254. https://doi.org/10.1080/15332861.2015.1028250

Jaska, E., \& Werenowska, A. (2014). The use of social media in communication and branding. Ekonomia i Prawo, $13(1), 47$. https://doi.org/10.12775/EiP.2014.004

Juodagalvienè, B. (2018). Vienbučiu namu projektiniu sprendiniu daugiakriteris parinkimas. Vilniaus Gedimino technikos universitetas.

Khan, I., \& Rahman, Z. (2016). E-tail brand experience's influence on e-brand trust and e-brand loyalty: The moderating role of gender. International Journal of Retail and Distribution Management, 44(6), 588-606. https://doi.org/10.1108/IJRDM-09-2015-0143

Khan, I., Rahman, Z., \& Fatma, M. (2016). The concept of online corporate brand experience: An empirical assessment. Marketing Intelligence and Planning, 34(5), 711-730. https://doi.org/10.1108/MIP-01-2016-0007

Klie, L. (2015). Social Media is now a viable Support Channel. CRM Magazine, 19(December), $24-28$. http://search.ebscohost.com/login.aspx?direct=true \&db=a9h\&AN=111298838\&site=ehost-live \&scope=site

Kramoliš, J., \& Kopečková, M. (2013). Product placement: A smart marketing tool shifting a company to the next competitive level. Journal of Competitiveness, 5(4), 98-114. https://doi.org/10.7441/joc.2013.04.06

Lallemand, C., Gronier, G., \& Koenig, V. (2015). User experience: A concept without consensus? Exploring practitioners' perspectives through an international survey. Computers in Human Behavior, 43, 35-48. https://doi.org/10.1016/j.chb.2014.10.048

Lamont, J. (2012). Tuning in to customers: Optimizing the online experience. KM World, 21(February), 8-9. http://search.ebscohost.com/login.aspx?direct=true\&db=a9h\&AN=70967856\&site=ehost-live

Lamont, J. (2014). Creating a positive customer experience. KM World, 23(2), 8-9. http://search.ebscohost.com/login.aspx?direct=true \&db=aph\&AN=94260890\&site=ehost-live \&scope=site

Liyakasa, K. (n.d.). Connecting retail and e-tail. CRM Magazine, 16(11), 44-48. $\mathrm{http} / / /$ search.ebscohost.com/login.aspx?direct=true \&db=a9h\&AN=82716612\&site=ehost-live

Luo, J., Ba, S., \& Zhang, H. (2012). The effectiveness of online shopping characteristics and well-designed websites on satisfaction. MIS Quarterly, 36(4), 1131-1144. https://doi.org/10.2307/41703501

MacDonald, R. (2012). The new social contact center, integrating social media into a seamless customer experience. $C R M$ Magazine, 16(3), WP10. http://search.ebscohost.com/login.aspx?direct=true \&db=a9h\&AN=74099584\&site=ehost-live

Martin, J., Mortimer, G., \& Andrews, L. (2015). Re-examining online customer experience to include purchase frequency and perceived risk. Journal of Retailing and Consumer Services, 25, 81-95. https://doi.org/10.1016/j.jretconser.2015.03.008

McLean, G., \& Wilson, A. (2016). Evolving the online customer experience ... is there a role for online customer support? Computers in Human Behavior, 60, 602-610. https://doi.org/10.1016/j.chb.2016.02.084

Meyers-Levy, J., \& Loken, B. (2015). Revisiting gender differences: What we know and what lies ahead. Journal of Consumer Psychology, 25(1), 129-149. https://doi.org/10.1016/j.jcps.2014.06.003

Micu, A. E., Bouzaabia, O., Bouzaabia, R., Micu, A., \& Capatina, A. (2019). Online customer experience in e-retailing: implications for web entrepreneurship. International Entrepreneurship and Management Journal, 15(2), 651-675. https://doi.org/10.1007/s11365-019-00564-x 
Ng, C. Y., \& Chuah, K. B. (2014). Evaluation of design alternatives' environmental performance using AHP and ER approaches. IEEE Systems Journal, 8(4), 1182-1189. https://doi.org/10.1109/JSYST.2013.2258217

Nilashi, M., \& Ibrahim, O. Bin. (2012). A model for detecting customer level intentions to purchase in B2C websites using TOPSIS and fuzzy logic rule-based system. Arabian Journal for Science and Engineering, 39(3), 1907-1922. https://doi.org/10.1007/s13369-013-0902-9

Osmani, F., \& Kochov, A. (2018). Definition of indicators for decision-making to contribute to sustainable development through cleaner production and resource efficiency by using the AHP method. Energetika, 64(3), 155-166. https://doi.org/10.6001/energetika.v64i3.3808

Pandey, S., \& Chawla, D. (2018). Online customer experience (OCE) in clothing e-retail: Exploring OCE dimensions and their impact on satisfaction and loyalty - Does gender matter? International Journal of Retail and Distribution Management, 46(3), 323-346. https://doi.org/10.1108/IJRDM-01-2017-0005

Pappas, I. O., Pateli, A. G., Giannakos, M. N., \& Chrissikopoulos, V. (2014). Moderating effects of online shopping experience on customer satisfaction and repurchase intentions. International Journal of Retail and Distribution Management, 42(3), 187-204. https://doi.org/10.1108/JJRDM-03-2012-0034

Petit, O., Velasco, C., \& Spence, C. (2019). Digital Sensory marketing: Integrating new technologies into multisensory online experience. Journal of Interactive Marketing, 45, 42-61. https://doi.org/10.1016/j.intmar.2018.07.004

Rawat, D. C., \& Sharma, R. M. (2014). Evolution of e-commerce in India. 1-12. http://www.pwc.in/assets/pdfs/publications/2014/evolution-of-e-commerce-in-india.pdf

Rezaei, S. (2014). Online repatronage intention: An empirical study among Malaysian experienced online shoppers. International Journal of Retail \& Distribution Management, 42(5), 390-421. https://doi.org/10.1108/IJRDM-03-2012-0026

Rose, S., Clark, M., Samouel, P., \& Hair, N. (2012). Online customer experience in e-retailing: An empirical model of Antecedents and Outcomes. Journal of Retailing, 88(2), 308-322. https://doi.org/10.1016/j.jretai.2012.03.001

Saaty, R. W. (1987). The analytic hierarchy process-what it is and how it is used. Mathematical Modelling, 9(3-5), 161-176. https://doi.org/10.1016/0270-0255(87)90473-8

Salmela, V. R., \& Vanni, S. (2013). Brightness and transparency in the early visual cortex. Journal of Vision, 13(7), 1-14. https://doi.org/10.1167/13.7.16

Sargent, J. (2016). Delivering effortless customer experiences with social media. CRM Magazine, $20(10), 7$. http://search.ebscohost.com/login.aspx?direct=true \&db=a9h\&AN=118713445\&site=ehost-live \&scope=site

Spapé, M. M., Hoggan, E. E., Jacucci, G., \& Ravaja, N. (2015). The meaning of the virtual Midas touch: An ERP study in economic decision making. Psychophysiology, 52(3), 378-387. https://doi.org/10.1111/psyp.12361

Stavljanin, V., \& Pantovic, V. (2017). Online customer experience: Implications for digital banking. Bankarstvo, 46(2), 100129. https://doi.org/10.5937/bankarstvo1702100S

Sunaga, T., Park, J., \& Spence, C. (2016). Effects of lightness-location congruency on consumers' purchase decision-making. Psychology \& Marketing, 33(11), 5-18. https://doi.org/10.1002/mar.20929

Tandon, U., Kiran, R., \& Sah, A. N. (2016). Customer satisfaction using website functionality, perceived usability and perceived usefulness towards online shopping in India. Information Development, 32(5), 1657-1673. https://doi.org/10.1177/0266666915621106

Thakur, R., \& Srivastava, M. (2015). A study on the impact of consumer risk perception and innovativeness on online shopping in India. International Journal of Retail and Distribution Management, 43(2), 148-166. https://doi.org/10.1108/IJRDM-06-2013-0128

Tom, A., Sangadi, R., \& Ament, L. (2017). Retailers need to adapt to the smart customer. Customer Relationship Management, 21(12), 38-40.

Wijaya, I. W. K., Rai, A. A. G., \& Hariguna, T. (2019). The impact of customer experience on customer behavior intention use in social media commerce, an extended expectation confirmation model: An empirical study. Management Science Letters, 9(2019), 2009-2020. https://doi.org/10.5267/j.msl.2019.7.005

Wolnowska, A. E., \& Konicki, W. (2019). Multi-criterial analysis of oversize cargo transport through the city, using the AHP method. Transportation Research Procedia, 39(2018), 614-623. https://doi.org/10.1016/j.trpro.2019.06.063

\section{VEIKSNIAI TURINTYS İTAKOS TEIGIAMOMS VARTOTOJŲ PATIRTIMS INTERNETE}

\section{Rasa SMALIUKIENĖ, Dominykas KREGŽDĖ}

Santrauka. Pagrindinis šio straipsnio tikslas yra nustatyti veiksnius ir įvertinti jų daromą ịtaką teigiamų vartotojo patirčių kūrimui internete. Tyrime naudojami metodai yra literatūros analizè veiksnių identifikavimui ir Analitinis Hierarchijos Procesas (angl. AH), Kendall ekspertu konkordacijos koeficientas ir TOPSIS metodas, igalinę ịvertinti identifikuotų veiksnių ịtaką teigiamų vartotojo patirčių kūrimui internete. Tyrimui atlikti buvo suformuotos dvi grupès. Vieną grupę sudarè ekspertai, turintys patirtị atitinkamoje srityje. Kitą grupę sudaré žmonès, kurie perka internetu. Tyrimas atskleidè, kaip kiekvienas veiksnys daro ịtaką teigiamai vartotojo patirčiai internete. Be to, buvo suranguotos įmonès, veikiančios toje pačioje srityje, atsižvelgiant ị tai, kaip kiekvienas analizuotas veiksnys daro jai ịtaką.

Raktažodžiai: internetinè aplinka, teigiama vartotojo patirtis, veiksniai, ittaka, dizainas, apsipirkimas internete. 